Tugas individu

Mata Kuliah : Matematika II

Oleh Dosen Pengampuh: JUSMAWATI,S.Pd., M.Pd

\title{
VOLUME LIMAS SEGIENAM
}

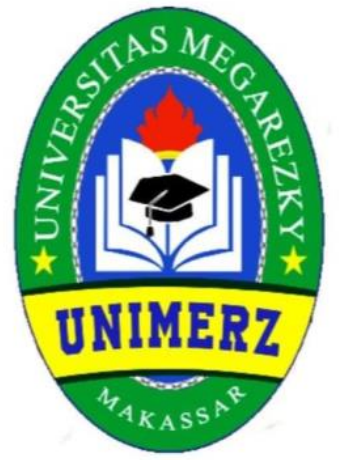

SEMESTER V

KRISTIANI

18093188206002

PROGRAM STUDI PENDIDIKAN GURU SEKOLAH DASAR

FAKULTAS KEGURUAN DAN ILMU PENDIDIKAN

\section{UNIVERSITAS MEGAREZKY}

TAHUN 2021 


\section{KATA PENGANTAR}

Puji syukur saya panjatkan kehadirat Tuhan yang Maha Esa karena berkat dan rahmatnya sehingga saya bisa menyelesaikan makalah ini dengan judul " VOLUME LIMAS SEGIENAM". Saya menyusun makalah ini untuk memenuhi tugas pada mata kuliah MATEMATIKA II. Saya pun menyadari bahwa penyusunan makalah ini masih jauh dari sempurna. Maka dari itu, saya mengharapkan kritik dan saran untuk membangun makalah ini.

Ucapan terima kasih juga saya sampaikan kepada pihak-pihak yang telah membantu dalam menyusun makalah ini. Semoga makalah ini bisa mendatangkan manfaat bagi kita semua.

Penyusun

KRISTIANI 


\section{DAFTAR ISI}

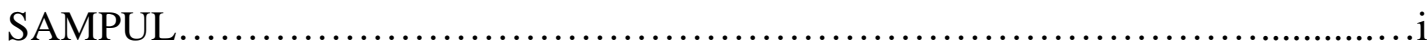

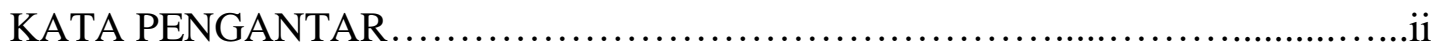

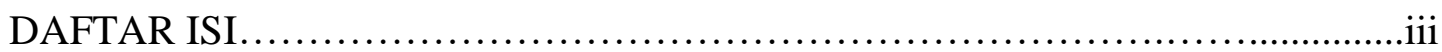

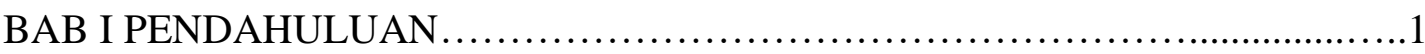

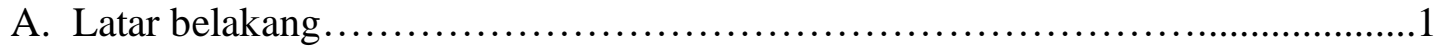

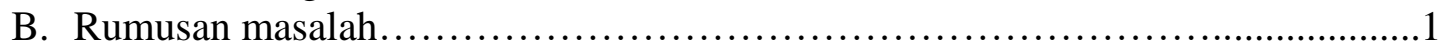

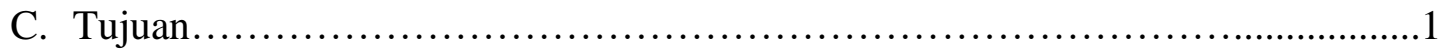

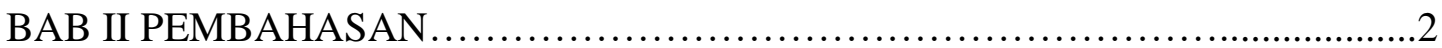

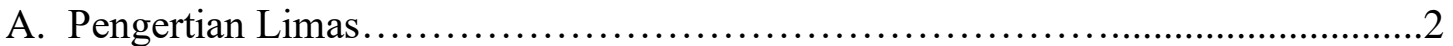

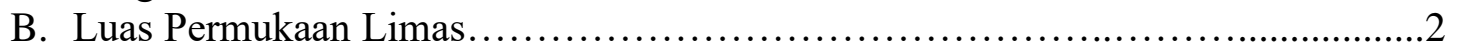

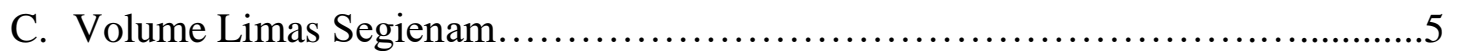

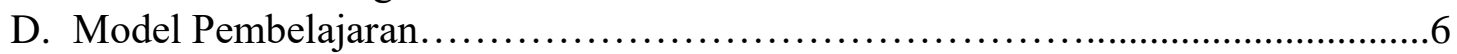

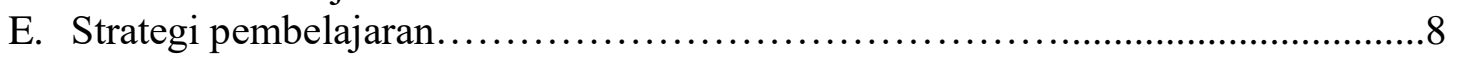

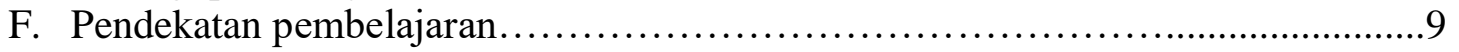

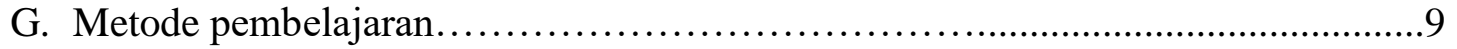

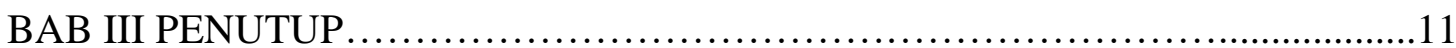

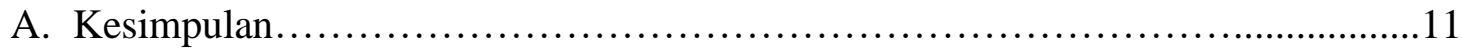

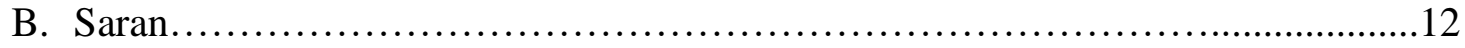

RENCANA PELAKSANAAN PEMBELAJARAN ......................................13

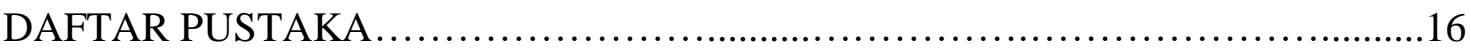




\section{BAB I \\ PENDAHULUAN}

\section{A. Latar Belakang}

Pendidikan abad 21 ditandai dengan adanya era revolusi industri 4.0. Pembelajaran dilaksanakan dengan berbasis daring (jusmawati, 2020 : 106),pembelajaran matematika dilakasanakan di sekolah dasar, dengan berbagai macam materi didalam matematika dikenal beberapa limas tiga dimensi yang memiliki panjang, lebar dan tinggi. Limas-limas ini tidak dapat digambar dengan pasti di atas bidang datar sehingga mereka merupakan bangun ruang. Limas memiliki bagian-bagian yang biasa kita kenal dengan sebutan titik sudut, rusuk, bidang sisi, luas permukaan dan volume.

Limas adalah salah satu bangun ruang yang ada di dalam pembahasan pelajaran matematika. Volume limas segienam Mempunyai ` 12 Buah titik rusuk, memiliki 7 buah titik sudut, 6 buah titik sudut terdapat di bagian alas sedangkan 1 buah titik sudut terdapat pada bagian atas atau puncak, mempunyai 7 buah sisi satu sisi terdapat pada bagian alas sedangkan 6 buah sisi lain terdapat pada bagian samping.

Pada makalah ini akan dibahas materi tentang volume limas segienam. Limas segi enam itu merupakan limas yang mempunyai alas yang berbentuk segi enam, baik itu segi enam sembarang maupun segi enam teratur.

\section{B. Rumusan Masalah}

1. Apa yang dimaksud dengan limas?

2. Apa saja ciri-ciri limas dan unsur-unsur dari limas?

3. Bagaimana cara menghitung luas permukaan limas?

4. Bagaimana cara menghitung volume limas segienam, sifat, dan rumus volume limas segienam?

5. Apa saja model yang sesuai dengan pembelajaran matematika?

6. Apa saja strategi yang sesuai denganpembelajaran matematika?

7. Apa saja pendekatan yang sesuai dengan pembelajaran matematika?

8. Apa saja metode yang sesuai dengan pembelajaran matematika?

\section{Tujuan}

1. Untuk mengetahui pengertian limas.

2. Untuk mengetahui ciri-ciri limas dan unsur-unsur dari limas.

3. Untuk mngetahui cara menghitung luas permukaan limas.

4. Untuk mengetahui cara menghitung volume limas segienam, sifat dan rumus volume limas segienam.

5. Untuk mengetahui model yang digunakan dalam matematika.

6. Untuk mengetahui strategi yang digunakan dalam pembelajaran matematika.

7. Untuk mengetahui pendekatan yang digunakan dalam matematika.

8. Untuk mengetahui metode yang digunakan dalam pembelajaran matematika. 


\section{BAB II \\ PEMBAHASAN}

\section{A. Pengertian Limas}

Limas adalah bangun ruang yang dibatasi oleh sebuah segi banyak (sebagai alas)dan beberapa sisi segitiga yang bertemu pada satu titik puncak.

Limas terdiri dari beberapa macam tergantung pada bentuk alasnya. Seperti prisma , nama limas juga berdasarkan jumlah segi-n sisi alasnhya. Apabila alas limas berupa segi-n beraturan da setiap sisi tegaknya merupakan segitiga sama kaki yang kongruen, maka limasnya disebut limas segi-n beraturan.

a) Ciri-Ciri Limas

Limas mempunyai ciri-ciri sebagai berikut :

a. Limas memiliki satu sisi alas dan tidak memiliki sisi atas (tutup).

b. Titik puncak dan titik sudut sisi alas dihubungkan oleh rusuk tegak.

c. Semua sisi tegak limas berbentuk segitiga.

b) Unsur-unsur Limas

Unsur-unsur yang dimiliki limas yaitu :

a. Titik sudut merupakan pertemuan 2 rusuk atau lebih.

b. Rusuk yaitu garis yg merupakan perpotongan antara 2 sisi limas.

c. Bidang sisi yaitu bidang yg terdiri dari bidang alas dan bidang sisi tegak.

d. Bidang alas yaitu bidang yang merupakan alas dari suatu limas.

e. Bidang sisi tegak yaitu bidang yag memotong bidang alas.

f. Titik puncak yaitu titik yang merupakan titik persekutuan antara selimutselimut limas.

g. Tinggi limas yaitu jarak antara bidanng alas dan titik puncak.

B. Luas Permukaan Limas

Jumlah daerah yang menjadi sisi pada alas dan sisi - sisi tegak pada limas merupakan luas permukaan limas. Sehingga, menjumlahkan sisi - sisi pada limas tersebut adalah cara untuk menghitung besar luas permukaan limas. Luas alas suatu limas dapat serupa segitiga, segi empat, segi lima, atau segi - n. Cara mencari luas alas tergantung dari bentuk alas limas.

a) Rumus Luas Permukaan Limas :

Luas permukaan merupakan jumlah luas bangun datar yang membentuk bangun ruang. Bangun datar yang membentuk limas terdiri dari sisi alas, dan bagian sisi tegak berbentuk segitiga. Sehingga, secara umum rumus luas permukaan limas yaitu sebagai berikut.

Rumus luas permukaan limas $=$ luas sisi alas + luas seluruh sisi tegak

Untuk mencari luas permukaan limas dapat di cari menggunakan rumus berikut ini :

$\mathbf{L}=$ Luas alas + luas selimut

$L=$ Luas alas $+1 / 4 \times$ keliling alas $x$ tinggi segitiga

\section{Contoh :}

a. Limas segi enam beraturan memiliki luas alas $120 \mathrm{~cm}^{2}$ dan luas segitiga tegak $30 \mathrm{~cm}^{2}$. Tentukan luas permukaan limas segi enam tersebut.

\section{Jawab :}

Diketahui:

luas alas $=120 \mathrm{~cm}^{2}$

luas segitiga tegak $=30 \mathrm{~cm}^{2}$ 
Ditanya : luas permukaan limas

\section{Penyelesaian :}

Luas permukaan $=$ luas alas + jumlah luas sisi tegak

luas alas $=120 \mathrm{~cm}^{2}$

jumlah luas sisi tegak $=6 \mathrm{x}$ luas segitiga tegak $=6 \times 30 \mathrm{~cm}^{2}=180 \mathrm{~cm}^{2}$

Jadi, luas permukaan limas segi enam $=120+180=300 \mathrm{~cm}^{2}$

b. Hitunglah luas permukaan limas dibawah ini.

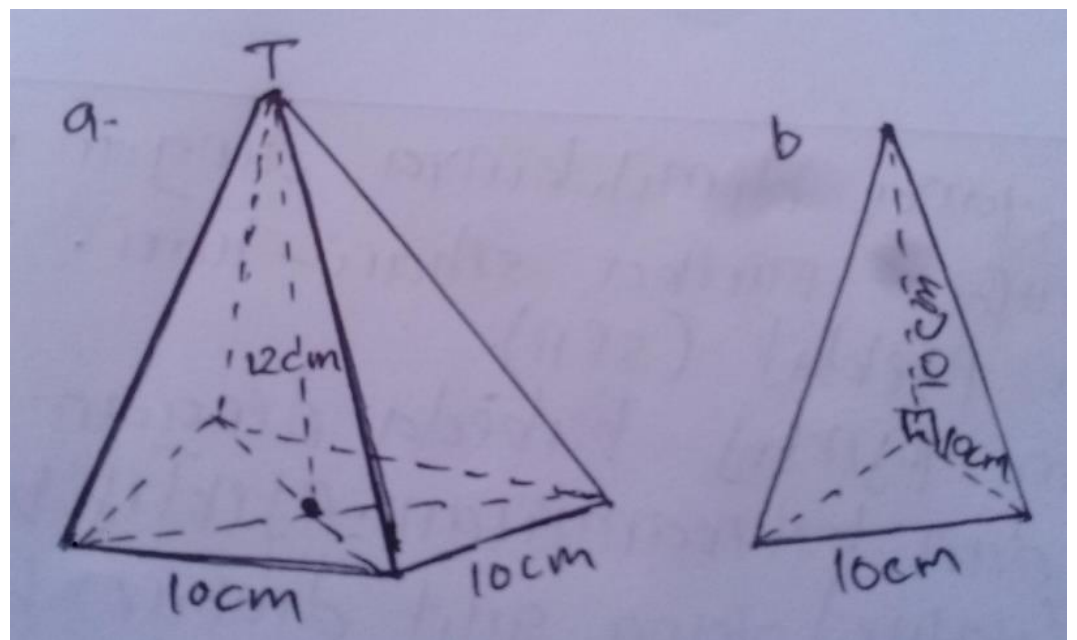

Pada soal ini limas mmepunyai 4 sisi tegak berbentuk segitiga. Tinggi segitiga dihitung dengan menggunakan rumus Pythagoras sebagai berikut: $($ Tinggi segitiga $) 2=(12 \mathrm{~cm}) 2+(5 \mathrm{~cm}) 2=144 \mathrm{~cm} 2+25 \mathrm{~cm} 2=169 \mathrm{~cm} 2$ $\begin{array}{lllll}\text { Tinggi segitiga }=\sqrt{ } 169 \quad \mathrm{~cm} & = & 13 & \mathrm{~cm}\end{array}$ Luas permukaan limas $=$ Luas alas $+(4 \mathrm{x}$ luas segitiga $)$ Luas permukaan limas $=(\mathrm{s} \times \mathrm{s})+(4 \times 1 / 2$. alas segitiga $\times$ tinggi segitiga $)$ Luas permukaan limas $=(10 \mathrm{~cm} \times 10 \mathrm{~cm})+(4 \times 1 / 2.10 \mathrm{~cm} .13 \mathrm{~cm})$ Luas permukaan limas $=100 \mathrm{~cm} 2+260 \mathrm{~cm} 2=360 \mathrm{~cm} 2$

\section{b) Volume Limas}

Rumus untuk mencari volume limas adalah :

Rumus Volume Limas yang akan kita bahas ketika ini dibatasi hanya untuk menghitung volume limas segitiga, volume limas segi empat, volume limas segi lima dan volume limas segi enam. Secara umum rumus untuk menghitung volume limas :

\section{Volume $=1 / 3 \times$ Luas_Allas $\times$ Tinggi}

Volume limas dapat diperoleh dari suatu kubus. Gambar di bawah menunjukan sebuah kubus yang panjang rusuknya s. Empat diagonal bidangnya saling berpotongan di titik $\mathrm{T}$. 

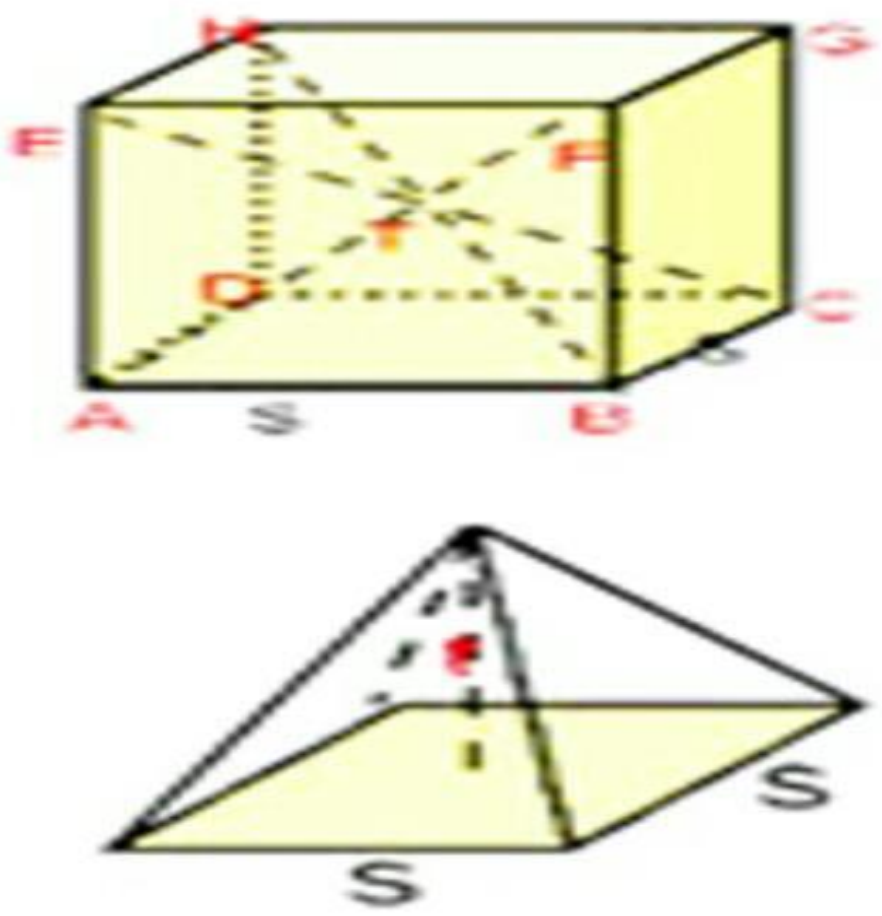

Kubus ABCD.EFGH terbagi menjadi enam limas yang kongruen, yaitu T.ABCD, T.BCGF, T.EFGH, T.ADHE, T.CDHG, T.ABFE. Salah satu limasnya ditunjukkan pada gambar di samping.

Contoh soal 8: volume limas segi enam

Sebuah limas segi enam mempunyai bantalan hexagon dengan panjang sisi $4 \mathrm{~cm}$. Bila tinggi limas $8 \mathrm{~cm}$. Berapakah volume limas tersebut?

- Semua limas tersebut mempunyai titik pusat

- Alasnya adalah semua bidang sisi kubus

- Tinggi limas sama dengan setengah panjang rusuk kubus $(t=1 / 2 s)$

Bila volume masing-masing limas adalah $\mathrm{V}$, maka jumlah volume enam limas sama dengan volume kubus.

Volume enam limas = volume kubus

$$
\begin{aligned}
& =\mathrm{s} \times \mathrm{s} \times \mathrm{s} \\
& =(\mathrm{s} \times \mathrm{s}) \times 1 / 2 \mathrm{~s} \times 2\left(\mathrm{~s} \times s=\mathrm{L}_{2} 1 / 2 \times \mathrm{s}=\mathrm{t}\right. \\
& =\mathrm{L} \times \mathrm{s} \times 2 \\
6 \mathrm{v} & =2 \mathrm{Lt} \\
& =2 / 6 \mathrm{Lt} \\
& =1 / 3 \mathrm{Lt} \\
& =1 / 3 \times \text { Luas alas } \times \text { tinggi }
\end{aligned}
$$

Volume limas $=1 / 3 \times$ luas alas $\mathrm{x}$ tinggi 


\section{Volume Limas segienam}

Limas segi enam itu merupakan limas yang mempunyai alas yang berbentuk segi enam, baik itu segi enam sembarang maupun segi enam teratur.

Limas segi enam ini memiliki sifat :

- Mempunyai `12 Buah titik rusuk

- Memiliki 7 buah titik sudut, 6 buah titik sudut terdapat di bagian alas sedangkan 1 buah titik sudut terdapat pada bagian atas atau puncak

- Mempunyai 7 buah sisi satu sisi terdapat pada bagian alas sedangkan 6 buah sisi lain terdapat pada bagian samping

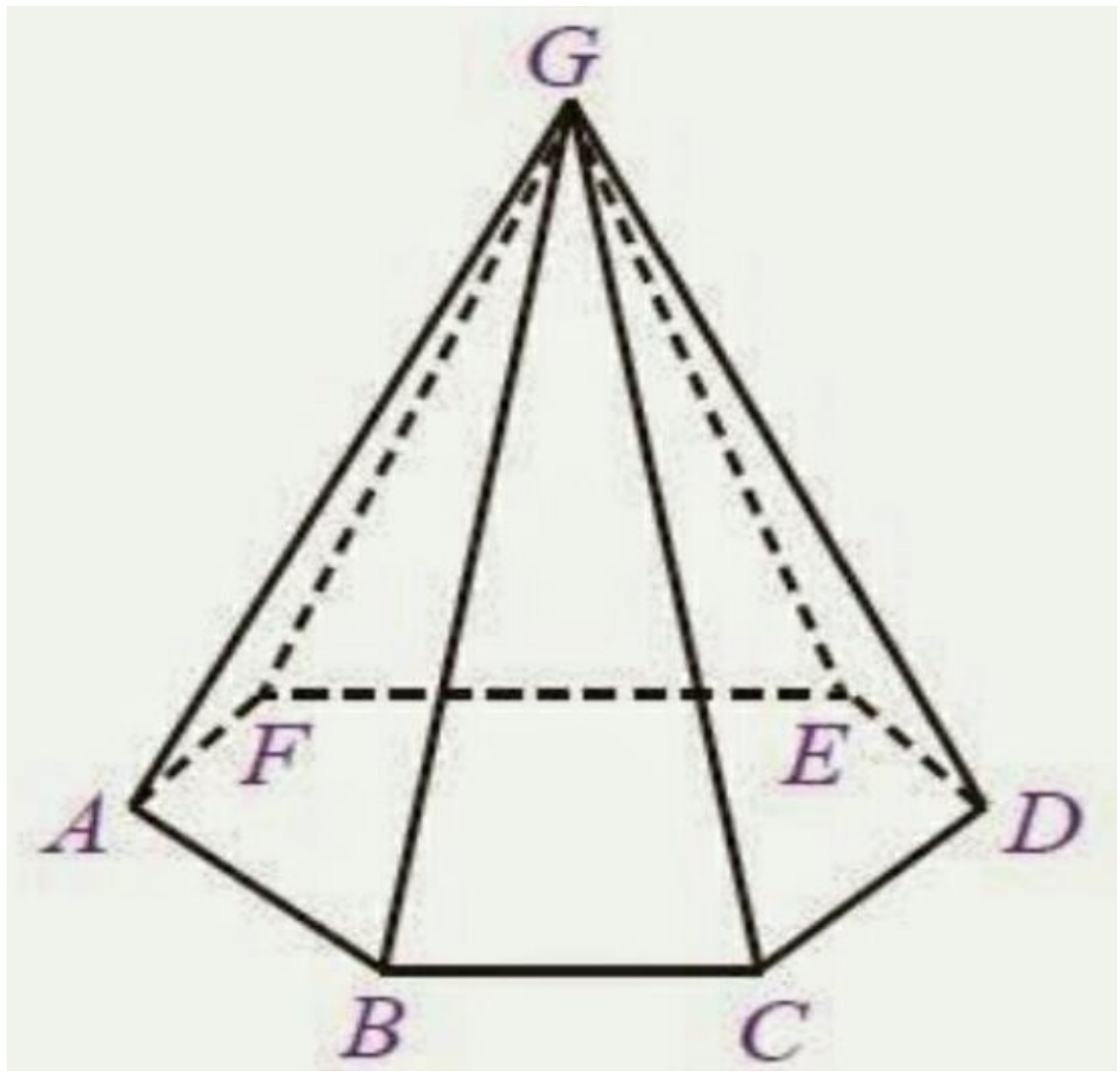

\section{Volume Limas Segi Enam}

Seperti yang lainnya, untuk menghitung volume limas yakni dengan memakai rumus umum : $\mathrm{V}=1 / 3 \mathrm{x}$ Lalas $\mathrm{x} t$. Dimana rumus untuk menghitung luas segienam sama sisi (heksagon) dengan panjang sisi a kita sanggup gunakan rumus :

$\mathrm{L}_{\text {segienam }}=\frac{3 \sqrt{3}}{2} S^{2}=25981 \mathrm{~s}^{2}$

Dengan demikian untuk menghitung volume limas dengan bantalan hexagon sanggup kita ubah menjadi:

$V=1 / 3 L_{\text {alas }} \times t$

$V=1 / 3 \times \frac{3 \sqrt{3}}{2} S^{2} \times t$

$V=1 / 3 \times 2,5981 s^{2} \times t$

$\mathbf{V}=\underline{\sqrt{3}} S^{2} \times t$ 
Atau

$V=\frac{1}{3} \times L_{\text {alas }} \times t$

\section{CONTOH SOAL 1 : VOLUME LIMAS SEGIENAM}

Sebuah limas segi enam mempunyai bantalan hexagon dengan panjang sisi $4 \mathrm{~cm}$. Bila tinggi limas $8 \mathrm{~cm}$. Berapakah volume limas tersebut?

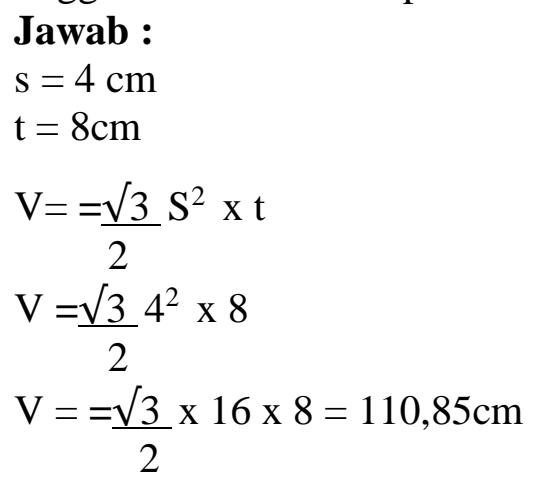

Jadi volume limas segienam tersebut adalah $110,85 \mathrm{~cm}$.

\section{CONTOH SOAL 2 :}

Sebuah limas segienam mempunyai volume $97 \mathrm{~cm}^{3}$. Bila tinggi limas $7 \mathrm{~cm}$. Berapakah panjang sisi limas tersebut?

Jawab:

$$
\begin{aligned}
& \mathrm{v}=97 \mathrm{~cm}^{3} \\
& \mathrm{t}=7 \mathrm{~cm} \\
& \mathrm{~V}=\frac{1}{3} \times 2,5981 \mathrm{~s}^{2} \times \mathrm{t} \\
& 97=\frac{1}{3} \times 2,5981 \mathrm{~s}^{2} \times 7 \\
& 97 \times \frac{3}{1} \times \frac{1}{7}=2,5981 \mathrm{~s}^{2} \\
& 97 \times \frac{3}{1} \times \frac{1}{7}=2,5981 \mathrm{~s}^{2} \\
& 41,5714=2,5891 \mathrm{~s}^{2} \\
& \mathrm{~S}^{2} \quad=\frac{41,5714}{2,5981}=16,0007
\end{aligned}
$$

$\mathrm{S}=\sqrt{ } 16,0007=4 \mathrm{~cm}$

Jadi panjang sisi limas segienam yaitu $4 \mathrm{~cm}$.

\section{Model Pembelajaran}

1. Model pembelajaran langsung

Menurut Arends (2001) dalam Trianto (2007: 29) model pembelajaran langsung adalah salah satu pendekatan mengajar yang dirancang khusus untuk menunjang proses belajar siswa yang berkaitan dengan pengetahuan deklaratif dan pengetahuan prosedural yang terstruktur dengan baik yang dapat diajarkan dengan pola kegiatan bertahap, selangkah demi selangkah. Menurut Sudrajat (2011) model pembelajaran langsung adalah model pembelajaran yang menekankan pada penguasaan konsep dan/atau perubahan perilaku dengan mengutamakan pendekatan deduktif, dengan ciriciri sebagai berikut: (1) transformasi dan ketrampilan secara langsung; (2) 
pembelajaran berorientasi pada tujuan tertentu; (3) materi pembelajaran yang telah terstuktur; (4) lingkungan belajar yang telah terstruktur; dan (5) distruktur oleh guru. Menurut Uno dan Nurdin (2011: 111) model pembelajaran langsung dapat berbentuk ceramah, demonstrasi, pelatihan atau praktik, dan kerja kelompok.

Dari berbagai pengertian di atas dapat disimpulkan model pembelajaran langsung adalah model pembelajaran untuk menyampaikan pelajaran yang ditransformasikan langsung oleh guru kepada siswa, menekankan penguasaan konsep, materi pembelajaran disampaikan dengan pola kegiatan bertahap, dan selangkah demi selangkah. Model pembelajaran langsung ini dapat diterapkan pada pembelajaran yang berorientasi kinerja dan transformasi keterampilan secara langsung seperti pembelajaran bermain musik.

Menurut Slavin (2003) dalam Sudrajat (2011) sintaks model pembelajaran langsung terdiri dari 7 tahap yaitu:

a. Menginformasikan tujuan pembelajaran dan orientasi pelajaran kepada siswa. Dalam tahap ini guru menginformasikan hal-hal yang harus dipelajari dan kinerja siswa yang diharapkan.

b. Me-review pengetahuan dan keterampilan prasyarat. Dalam tahap ini guru mengajukan pertanyaan untuk mengungkap pengetahuan dan keterampilan yang telah dikuasai siswa.

c. Menyampaikan materi pelajaran. Dalam fase ini, guru menyampaikan materi, menyajikan informasi, memberikan contoh-contoh, mendemontrasikan konsep dan sebagainya.

d. Melaksanakan bimbingan. Bimbingan dilakukan dengan mengajukan pertanyaan-pertanyaan untuk menilai tingkat pemahaman siswa dan mengoreksi kesalahan konsep.

e. Memberikan kesempatan kepada siswa untuk berlatih. Dalam tahap ini, guru memberikan kesempatan kepada siswa untuk melatih keterampilannya atau menggunakan informasi baru secara individu atau kelompok.

f. Menilai kinerja siswa dan memberikan umpan balik. Guru memberikan reviu terhadap hal-hal yang telah dilakukan siswa, memberikan umpan balik terhadap respon siswa yang benar dan mengulang keterampilan jika diperlukan.

g. Memberikan latihan mandiri. Dalam tahap ini, guru dapat memberikan tugastugas mandiri kepada siswa untuk meningkatkan pemahamannya terhadap materi yang telah mereka pelajari.

2. Model Kooperatif

Pembelajaran kooperatif (cooperative learning) merupakan bentuk pembelajaran dengan cara siswa belajar dan bekerja dalam kelompok-kelompok kecil secara kolaboratif yang anggotanya terdiri dari empat sampai enam orang dengan struktur kelompok yang bersifat heterogen. Pada hakikatnya cooperative learning sama dengan kerja kelompok.Nurulhayati, mengemukakan lima unsur dasar model cooperative learning, yaitu:

a. Ketergantungan yang positif,

b. Pertanggungjawaban individual,

c. Kemampuan bersosialisasi,

d. Tatap muka,

e. Evaluasi proses kelompok.

Ada dua komponen pembelajaran kooperatif, yakni :

- Cooperative task atau tugas kerja sama.

- Cooperative incentive structure, atau struktur intensif kerja sama. 


\section{E. Strategi Pembelajaran}

1. Strategi Pembelajaran Ekspositori (SPE)

Strategi pembelajaran ekspositori adalah strategi pembelajaran yang menekankan kepada proses penyampaian materi secara verbal dari seorang guru kepada sekelompok siswa dengan maksud agar siswa dapat menguasai materi pembelajaran secara optimal.

Prinsip-prinsip penggunaan strategi pembelajaran ekspositori

a. Berorientasi pada tujuan

Walaupun penyampaian materi pelajaran merupakan ciri utama dalam strategi pembelajaran ekspositori melalui metode ceramah, namun tidak berarti proses penyampaian materi tanpa tujuan pembelajaran; justru tujuan itulah yang harus menjadi pertimbangan utama dalam penggunaan strategi ini.

b. Prinsip komunikasi

Proses pembelajaran dapat dikatakan sebagai sebagai proses komunikasi, yang menunjukkan pada proses penyampaian pesan dari seseorang (sumber pesan) kepada seseorang atau sekelompok orang (penerima pesan).

c. Prinsip kesiapan

Dalam teori belajar koneksionisme, "kesepian" merupakan salah satu hukum belajar.

d. Prinsip berkelanjutan.

Proses pembelajaran ekspositori harus dapat mendorong siswa untuk mau mempelajari materi pelajaran lebih lanjut.

Keberhasilan penggunaan strategi ekspositori sangat tergantung pada kemampuan guru untuk bertutur atau menyampaikan materi pelajaran. Ada beberapa langkah dalam penerapan strategi ekspositori, yaitu:

- Persiapan (preparation)

- Penyajian (presentation)

- Menghubungkan (correlation)

- Menyimpulkan (generalization)

- Penerapan (aplication)

\section{Strategi pembelajaran Inquiri}

Strategi pembelajaran inquiri adalah rangkaian kegiatan pembelajaran yang menekankan pada proses berfikir dan mencari jawaban masalah yang strategiheyristic, yang berasal dari bahasa Yunani, yaitu heuriskein yang berarti saya menemukan . SPI berangkat dari asumsi bahwa sejak manusia lahir ke dunia, manusia memiliki dorongan untuk menemukan sendiri pengetahuannya. Rasa ingin tahu tentang keadaan alam sekitarnya merupakan kodrat manusia sejak ia lahir ke dunia. Sejak kecil manusia memiliki keinginan untuk mengenal segala sesuatu melalui indra pengecapan,pendengaran, penglihatan, dan indra indra lainnya yang berkembang dengan menggunakan otak dan pemikirannya.

Tujuan strategi pembelajaran inquiri :

a. Meningkatkan keterlibatan peserta didik dalam menemukan dan memproses bahan belajarnya,

b. Mengurangi ketergantungan peserta didik pada guru untuk mendapatkan pengalaman belajarnya, 
c. Melatih peserta didik menggali dan memanfaatkan lingkungan sebagai sumber belajarnya,

d. Memberi pengalaman belajar seumur hidup.

Adapun ciri utama strategi pembelajaran inquiri.

- Strategi inquiri menekankan pada aktivitas siswa secara maksimal untuk mencari dan menemukan. Artinya strategi inquiri menempatkan siswa sebagai subjek belajar.

- Seluruh aktivitas siswa diarahkan untuk mencari dan menemukan jawaban sendiri sesuatu yang di pertanyakan, sehingga menumbuhkan rasa percaya diri.

- Strategi inquiri bertujuan untuk mengembangkan kemampuan berfikir secara sistematis, logis, dan kritis, atau mengembangkan kemampuan intelektual sebagai bagian dari proses mental.

\section{Strategi Pembelajaran Kooperatif}

Model pembelajaran kelompok adalah rangkaian kegiatan belajar yang dilakukan oleh siswa dalam kelompok-kelompok tertentu untuk mencapai tujuan pembelajaran yang telah dirumuskan. Ada empat unsur penting dalam strategi pembelajaran kooperatif yaitu: (a) adanya peserta dalam kelompok, (b) adanya aturan kelompok, (c) adanya upaya belajar setiap kelompok, dan (d) adanya tujuan yang harus dicapai dalam kelompok belajar.. Strategi pembelajaran kooperatif merupakan model pembelajaran dengan menggunakan sistem pengelompokan/tim kecil, yaitu antara empat sampai enam orang yang mempunyai latar belakang kemampuan akademik, jenis kelamin, ras, atau suku yang berbeda (heterogen), sistem penilaian dilakukan terhadap kelompok. Setiap kelompok akan memperoleh penghargaan (reward), jika kelompok tersebut menunjukkan prestasi yang dipersyaratkan.

\section{F. Pendekatan Pembelajaran}

1) Pendekatan saintifik

Pendekatan saintifik merupakan pembelajaran yang berpusat kepada siswa, bukan pada guru. Guru hanya sebagai fasilitator. Pendekatan saintifk berisikan proses pembelajaran yang didesain agar siswa mengalami belajar secara aktif melalui suatu tahapan-tahapan. Pendekatan saintifik dilahirkan atas munculnya kurikulum 2013. Pendekatan saintifik disebut juga pendekatan ilmiah yang berati konsep dasar yang menginspirasi atau melatarbelakangi perumusan metode mengajar dengan menerapkan karakteristk yang ilmiah. Pendekatan saintifik( scientifict approach) merupakan bagian dari pendekatan pedagogis pada pelaksanaan pembelajaran.

Proses pembelajaran yang mengimplementasikan pendekatanm saintifik akan menyentuh tiga ranah, yaitu; sikap(afektif), pengetahuan(kogniti), dan keterampilan(psikomotor). Dengan proses pembelajaran yang demikian maka diharapkan hasil belajar melahirkan peserta didik yang produktif, kreatiif, inovatif, dan afektif melalui penguatan sikap, keterampilan, dan pengetahuan yang terintegrasi. Perhatikan diagram berikut.

\section{G. Metode Pembelajaran}

\section{Metode Diskusi}

Menurut Djamalah (2006 : 87), "Metode diskusi adalah cara penyajian pelajaran dimana siswa - siswa dihadapkan kepada suatu masalah yang biasa berupa pernyataan atau pertanyaan yang bersifat problematic untuk dibahas dan dipecahkan bersama ". Metode diskusi adalah metode mengajar yang sangat erat hubungannya dengan belajar memecahkan masalah (problem solving).

Teknik diskusi adalah salah satu teknik belajar mengajar yang dilakukan seorang guru disekolah. Didalam diskusi ini proses belajar mengajar terjadi dimana interaksi 
antara dua atau lebih individu terlibat, saling tukar menukar pengalaman,informasi,memecahkan masalah, dapat terjadi juga semuanya aktif tidak ada yang aktif sebagai pendengar saja.

Metode diskusi ialah metode menyajikan pelajaran dimana siswa dihadapkan kepada suatu masalah untuk dipecahkan bersama dalam bentuk kelompok dan juga dapat menyimpulkan hasil diskusinya. Dalam penelitian ini siswa diminta untuk membentuk kelompok dan duduk bersama dalam kelompok masing - masing untuk mendengarkan penjelasan materi fotosintesis yang disampaikan.

\section{Metode Tanya Jawab}

Metode Tanya jawab adalah cara penyajian pelajaran dalam bentuk pertanyaan yang harus dijawab, terutama dari guru kepada siswa, tetapi dapat pula dari siswa kepada guru. Hal ini sejalan dengan pendapat Sudirman (1987 : 120) yang mengartikan bahwa "Metode Tanya Jawab adalah cara penyajian pelajaran dalam bentuk pertanyaan yang harus dijawab terutama dari guru kepada siswa, tetapi dapat pula dari siswa kepada guru."

Metode Tanya jawab adalah suatu metode pembelajaran yang dilakukan dengan cara pengajuan - pengajuan pertanyaan yang mengarahkan siswa untuk memahami materi pelajaran dalam rangka mencapai tujuan pelajaran. Penggunaan metode ini dengan baik dan tepat, akan dapat merangsang minat dan motivasi siswa dalam belajar.

\section{Metode Penugasan}

Metode Penugasan atau metode pemberian tugas adalah cara dala proses belajar mengajar dengan jalan memberi tugas kepada siswa. Tugas - tugas itu dapat berupa mengikhtisarkan karangan, (dari surat kabar, majalah atau buku bacaan) membuat kliping, mengumpulkan gambar,perangko, dan dapat pula menyusun karangan.

Dalam proses pembelajaran, siswa hendaknya didorong untuk melakukan kegiatan yang dapat menumbuhkan proses kegiatan kreatif. Oleh karena itu, metode pemberian tugas dapat dipergunakan untuk mendukung metode pembelajara lain. 


\section{A. Kesimpulan}

\section{BAB III \\ PENUTUP}

Limas adalah bangun ruang yang dibatasi oleh sebuah segi banyak (sebagai alas)dan beberapa sisi segitiga yang bertemu pada satu titik puncak.

Limas terdiri dari beberapa macam tergantung pada bentuk alasnya. Seperti prisma , nama limas juga berdasarkan jumlah segi-n sisi alasnhya. Apabila alas limas berupa segi-n beraturan da setiap sisi tegaknya merupakan segitiga sama kaki yang kongruen, maka limasnya disebut limas segi-n beraturan.

Limas mempunyai ciri-ciri sebagai berikut :

- Limas memiliki satu sisi alas dan tidak memiliki sisi atas (tutup).

- Titik puncak dan titik sudut sisi alas dihubungkan oleh rusuk tegak.

- Semua sisi tegak limas berbentuk segitiga.

Unsur-unsur yang dimiliki limas yaitu :

- Titik sudut merupakan pertemuan 2 rusuk atau lebih.

- Rusuk yaitu garis yang merupakan perpotongan antara 2 sisi limas.

- Bidang sisi yaitu bidang yang terdiri dari bidang alas dan bidang sisi tegak.

- Bidang alas yaitu bidang yang merupakan alas dari suatu limas.

- Bidang sisi tegak yaitu bidang yang memotong bidang alas.

- Titik puncak yaitu titik yang merupakan titik persekutuan antara selimutselimut limas.

- Tinggi limas yaitu jarak antara bidanng alas dan titik puncak.

\section{Rumus Luas Permukaan Limas :}

Luas permukaan merupakan jumlah luas bangun datar yang membentuk bangun ruang. Bangun datar yang membentuk limas terdiri dari sisi alas, dan bagian sisi tegak berbentuk segitiga. Sehingga, secara umum rumus luas permukaan limas yaitu sebagai berikut.

Rumus luas permukaan limas = luas sisi alas + luas seluruh sisi tegak

Untuk mencari luas permukaan limas dapat di cari menggunakan rumus berikut ini :

$\mathrm{L}=$ Luas alas + luas selimut

$L=$ Luas alas $+1 / 4 \times$ keliling alas $x$ tinggi segitiga

\section{Limas Segienam}

Limas segi enam itu merupakan limas yang mempunyai alas yang berbentuk segi enam, baik itu segi enam sembarang maupun segi enam teratur.

Limas segi enam ini memiliki sifat :

- Mempunyai `12 Buah titik rusuk 
- Memiliki 7 buah titik sudut, 6 buah titik sudut terdapat di bagian alas sedangkan 1 buah titik sudut terdapat pada bagian atas atau puncak

- Mempunyai 7 buah sisi satu sisi terdapat pada bagian alas sedangkan 6 buah sisi lain terdapat pada bagian samping

\section{Volume Limas Segi Enam}

Seperti yang lainnya, untuk menghitung volume limas yakni dengan memakai rumus umum : $\mathrm{V}=1 / 3 \mathrm{x}$ Lalas $\mathrm{x} \mathrm{t}$.

$$
\mathrm{L}_{\text {segienam }}=\underline{3 \sqrt{3}} S^{2}=25981 s^{2}
$$

2

Dengan demikian untuk menghitung volume limas dengan bantalan hexagon sanggup kita ubah menjadi:

$\mathrm{V}=\mathbf{1 / 3} \mathrm{L}_{\text {alas }} \times \mathrm{t}$

$$
\begin{gathered}
V=1 / 3 \times \underset{2}{3 \sqrt{3}} S^{2} \times t \\
V=1 / 3 \times 2,5981 s^{2} \times t \\
V=\frac{\sqrt{3}}{2} S^{2} \times t
\end{gathered}
$$

$$
\begin{aligned}
& \text { Atau } \\
& V=\frac{1}{3}
\end{aligned} L_{\text {alas }} \times t
$$

B. Saran

Dengan adanya makalah ini kita diharapkan mampu memahami materi tentang Volume limmas segienam dalam pelajaran matematika . Dan saya meminta maaf atas kekurangan didalam penulisan makalah ini. Oleh karena itu, sangat mengharapkan kritik dan saran yang membangun agar makalah ini dapat lebih baik lagi. Semoga makalah ini bermanfaat bagi semua pembaca. 


\title{
RENCANA PELAKSANAAN PEMBELAJARAN
}

(RPP)

\author{
Nama Mahasiswa $\quad$ KRISTIANI \\ Mata Pelajaran : Matematika \\ Kelas/Semester $\quad: \mathrm{Vl} / 2$ \\ Judul Materi $\quad$ : Volume Limas Segienam
}

A. STANDAR KOMPETENSI:

1. Memahami luas permukaan limas, volume limas segienam.

B. KOMPETENSI DASAR

1.1. Menghitung luas permukaan limas dan volume limas segienam

C. INDIKATOR

1.2 Menjelaskan pengertian limas, ciri-ciri limas dan unsur-unsur limas

1.3 Menghitung luas permukaan limas dan rumus luas permukaan limas

1.4 Menghitung volume limas, volume limas segienam serta sifat-sifatnya

D. TUJUAN PEMBELAJARAN

- Siswa dapat menjelaskan pengertian limas, ciri-ciri limas dan unsur-unsur limas

- Siswa dapat menghitung rumus luas permukaan limas

- Siswa dapat menentukan rumus volume limas segienam serta sifat-sifatnya

E. MATERI POKOK

Volume Limas Segienam

F. MODEL, STRATEGI, PENDEKATAN DAN METODE

Model : Langsung, kooperatif

Strategi :Ekspositori, inquiry, kooperatif,

Pendekatan : Saintific,

Metode : Diskusi, tanya jawab dan penugasan

G. LANGKAH-LANGKAH PEMBELAJARAN 


\begin{tabular}{|l|l|l|}
\hline Kegiatan & Deskripsi Kegiatan & Alokasi \\
Waktu
\end{tabular}

\section{H. SUMBER PEMBELJARAN}

- Senang Belajar Matematika Buku Guru SD/MI Kelas 6 cetakan ke-1 Jakarta : Kementerian Pendidikan dan Kebudayaan, 2018.

- Buku Matematika Untuk SD/MI Kelas VI Kurikulum 2013 Revisi, Jakarta : PT. Gelora Aksara Pratama.

\section{I.PENILAIAN PEMBELAJARAN \\ - TeknikPenilaian}

a. PenilaianSikap:Tanggungjawab, Kerja sama,dan Peduli.

b. PenilaianPengetahuan:Tanya jawab, Pengamatan, dan Essay. 
c. Penilaian Keterampilan:unjukkerja.

Mengetahui

Makassar, 6 Februari2021

Dosen Pengampuh,

Mahasiswa

JUSMAWATI S.Pd, M.Pd

KRISTIANI 


\section{DAFTAR PUSTAKA}

Https://www.cara.aimyaya.com/2016/01/volume-limas.html?m=1 Https://blog.iccankoon.blogspot.com/2017/10/makalah-limas.html?m=1 Https://idschool.net/smp/rumus-volume-dan-luas-permukaan-limas/ Sudrajat, A. 2011. Model Pembelajaran Langsung (Direct Instruction).Http://akhmadsudrajat.wordpress.com(diakses tanggal 1 Maret 2012)

Trianto. 2007. Model-model Pembelajaran Inovatif Beroriontasi Konstruktivistik. Jakarta: Prestasi Pustaka Publisher

Mappasoro. (2014). Strategi Pembelajaran, Makassar : Universitas Negeri Makassar.

Sanjaya, Wina. ( 2006). Strategi Pembelajaran Berorientasi Standar Proses Pendidikan. Bandung : Kencana Prenada Media Group.

Sumiati dan Asra. Metode Pembelajaran. Bandung. CV Wacana Prima. 2009. Hlm. 92-96

Musfiqon dan Nurdyansyah.2015. Pendekatan Pembelajaran Saintifik, (Sidoarjo: Nizamila Learning Center.

Jusmawati, J., Satriawati, S., \& Sabillah, B. M. (2020). Pengaruh Pembelajaran Berbasis Daring Terhadap Minat Belajar Mahasiswa Pgsd Unimerz Pada Mata Kuliah Pendidikan Matematika. JKPD (Jurnal Kajian Pendidikan Dasar), 5(2), 106-111. 